\title{
Lightweight FRC infill wall: in-plane and out-of-plane loading tests
}

\author{
Adriano Reggia (i) - Alessandro Morbi • Marco Preti · Giovanni A. Plizzari
}

Received: 1 October 2019/Accepted: 9 October 2020/Published online: 21 October 2020

(C) The Author(s) 2020

\begin{abstract}
The continued interest in technological innovation in construction has greatly broadened the horizons of material science, developing a specific sector closely related to the recycling of waste products. This paper examines the thermal, mechanical and structural behaviour of an insulating light weight fibre reinforced concrete (ILWFRC), which is made by replacing natural sand and gravel with artificial aggregates resulting from the process of glass recycling. ILWFRC offers low density (approximately $650 \mathrm{~kg} / \mathrm{m}^{3}$ ), excellent thermal characteristics (thermal conductivity $0.1 \mathrm{~W} / \mathrm{mK}$ ), a compressive strength similar to brick masonry (3.5 MPa) with low cement content $\left(265 \mathrm{~kg} / \mathrm{m}^{3}\right)$ and stable postcracking behaviour. The mechanical and physical properties of ILWFRC were employed for the construction of a full-scale infill wall (having dimensions of $2.9 \times 2.6 \times 0.2 \mathrm{~m}$ ), which was experimentally studied under in-plane and out-of-plane actions. Inplane response showed a maximum lateral load of $359 \mathrm{kN}$ at $1.5 \%$ drift, with a residual capacity of more than $75 \%$ at $4 \%$ drift. The subsequent out-of-plane test
\end{abstract}

A. Reggia ( $₫)$ · M. Preti · G. A. Plizzari

Department of Civil, Environmental, Architectural Engineering and Mathematics, University of Brescia, Via Branze, 43, 25123 Brescia, Italy

e-mail: adriano.reggia@unibs.it

\section{A. Morbi}

Global Product Innovation, Heidelberg Cement Group,

Bergamo, Italy was performed up to failure with a maximum lateral load of $67 \mathrm{kN}$, corresponding to about 7 times the infill self-weight.

Keywords Artificial aggregates $\cdot$ Circular economy $\cdot$ Fibre reinforced concrete $\cdot$ Infill wall · Performance levels - Insulating concrete $\cdot$ Recycling · Quasi-static cyclic response

\section{Research significance}

In order to address the challenges of Directive 2002/ 91/EC on the energy performance of buildings [1] and of Directive 2008/98/EC on waste [2], several new construction materials have been developed over the years. Among these, and the focus of this article, is an innovative material, called insulating light-weight fibre reinforced concrete (ILWFRC). This new cement-based material is characterised by a reduced unit weight and excellent thermal and mechanical characteristics, due to the presence of $70 \%$ (by volume) lightweight recycled glass aggregates (patented by [3]) and synthetic fibres. These characteristics make it suitable for use in large structural and non-structural elements which are subject to moderate compressive stresses, such as load-bearing walls, partitions and infill walls. In this paper, an ILWFRC infill prototype is investigated. The characteristics of 
the material allow the accomplishment of thermal performance limits imposed by national codes with a single layer of material, avoiding the use of additional insulating materials. This innovative solution for infills offers, in comparison with traditional solid masonry infills, similar lateral resistance, larger ductility and a more stable out-of-plane response.

\section{Introduction}

Infill walls are usually considered non-structural elements in design practice and their interaction with the structure is often neglected by designers [4]. However, their role in the seismic response is not negligible and design standards typically suggest to indirectly control their response by limiting the bare structure drift demand. For example, in Eurocode 8 [5], the inter-story drift of RC framed structures can be limited in such way to avoid the risk of collapse of infill walls and excessive damage at the Serviceability Limit State. In the case of brittle infills rigidly connected to the frame, this drift limit is set to $0.5 \%$.

In fact, with less than $0.5 \%$ drift, the infill can be not damaged or even slightly damaged. For higher drift values, infill can experience extensive damage, resulting in a reduction of the load-bearing capacity for inplane actions, or a loss of stability for out-of-plane actions $[6,7]$. The out-of-plane collapse of an infill or the fall of debris from above can put human lives at risk [8]. In addition, shear failure of the column can occur if the infill strength is too high, with even more serious consequences [9-15]. Experimental studies on infills [16-20] have shown that loss of stability out-ofplane can be correlated with the reduction in loadbearing capacity in the plane of the frame. For instance, at a drift of $0.5 \%$, the out-of-plane strength can be reduced by $74 \%$.

For these reasons, scientific interest in the behaviour of masonry infills has become more relevant in recent years. Several aspects of the behaviour of traditional infills, including their behaviour in existing reinforced concrete structures, have been investigated and several innovative solutions have been proposed by various research groups. However, a widely accepted solution has not yet been identified [21].

The traditional solution consists of the construction of a masonry inside a framed structure, generally made of reinforced concrete (RC), and in complete contact with the surrounding frame, both at the sides (with the columns) and above (with the beams). With this type of infill, the contact detail is generally very poor, with no connection elements or pre-defined gaps. This system traditionally has been adopted in RC structures in many countries and is still widespread today. Recent post-earthquake surveys [22-25] have shown how these elements can be involved in failures due to seismic actions both in-plane and out-of-plane. These failure cause considerable economic loss and can pose a serious threat to human life, even without the complete collapse of the entire building.

Innovative solutions, aiming to obtain a predictable and ductile response of the infills in contrast with traditional masonry infills (which structural response is often brittle and unpredictable) follow three alternative approaches [26].

The first approach aims to completely decouple the infill from the structure, using flexible joints between the frame and the panel and providing out-of-plane stability with special restraint systems [27-31]. The implementation of these systems requires a detailed study of the material filling the gap and the design of the out-of-plane restraint system. Although this solution is straightforward, an inadequate design may lead to two potential issues: an unforeseeable partial reduction of decoupling (affecting the structural level) or unexpected damage to the infill itself.

The second approach is represented by the search for a construction detail which is able to reduce the detrimental interaction of infill with the RC structure [32-35]. For instance, the insertion of sliding elements (e.g. simple wooden planks) between the infill elements (e.g. bricks or blocks) creates weak planes and divides the panel into smaller elements. This solution aims to reduce the interaction between the infill and the frame, concentrate damage in selected areas, and thus control the failure mechanism of the infill. The contribution of the infills to the inter-storey shear is, in this case, significantly reduced and the structural response becomes closer to that of the bare frame. Among the decoupling techniques, the construction of masonry with horizontal sliding joints has demonstrated, through experimental and numerical investigations, to be an effective solution in limiting the damage of the infill even in the case of severe earthquakes.

Finally, the third approach is represented by the search for methods of enhancing the strength and 
ductility of the infills to enable them to carry seismic loads through the inclusion of reinforcing elements such as vertically or horizontally arranged metal bars or light trusses, meshes made of steel wire or other materials such as carbon fibre reinforced polymer (CFRP) [36] or fibre reinforced cementitious matrix (FRCM) [37].

With reference to the latter category of infill walls, an innovative system has been developed with the aim of reducing seismic vulnerability of the infill by increasing its strength and ductility, in addition to adequate thermal and acoustic efficiency and durability, through the use of the innovative cement-based material (ILWFRC) cast in place directly inside the frame. The originality of this study lies in the use of an innovative material, the unique characteristics of the mixture, and the way the non-structural element is made: not by assembling parts (bricks, blocks, reinforcing elements etc.), but with a single cast of fibrereinforced concrete and without other reinforcing elements. The system is being investigated for the first time to verify the feasibility of its use as a replacement for traditional infill panels for newly designed reinforced concrete buildings. The advantages of this solution could include the increased speed of construction, compliance with thermal performance limits and safety against seismic actions.

In the first part of this paper, thermal and mechanical properties of ILWFRC are described, with reference to the innovative mix design of the material. In the second part, the results of an experimental test of a full-scale infill wall $(2.9 \times 2.6 \times 0.2 \mathrm{~m})$, made with ILWFRC, performed using a testing structure designed to simulate the in-plane and out-of-plane seismic demand to the infill are presented. Experimental results are described in terms of capacity and damage pattern, focusing on the lateral load-drift response, the development of the crack pattern and gap between the frame and the infill wall, the variation of lateral stiffness and the energy dissipation during cycles. In the last section, drift limits, associated with different performance levels, are evaluated and a comparison with the response of other infill solutions (traditional and innovative), tested in the same reusable confining frame, is made.

\section{ILWFRC material}

\subsection{Field of application}

With the aim of avoiding critical issues related to the combination of organic insulating materials (polystyrene or polyurethane) and heavy-weight materials (concrete or clay hollow bricks), or related to the use of autoclaved aerated concrete (AAC) bricks, a new cement-based material has been developed and patented by Cangiano et al. [3]. The field of application of ILWFRC mainly concerns infill walls (nonstructural elements), satisfying thermal requirements for energy savings, environmental requests in terms of use of secondary raw materials and seismic performance for earthquake prone regions. In some circumstances, ILWFRC could be also used for the construction of structural walls, as a possible alternative to masonry walls.

\subsection{Mix design}

The binder used in ILWFRC was an ordinary Portland cement (CEM Type II 42.5R). The water/cement ratio (w/c) was 0.65 while the aggregate/cement volume ratio is equal to 8 . The volume fraction of macrosynthetic fibres was $0.4 \%$. Air entraining agent, superplasticizer and viscosity modifier admixture were also used. The mix design of ILWFRC is given in Table 1.

Lightweight aggregates were obtained from glass industrial recycling, namely granulated expanded glass (GEG) and crushed expanded glass (CEG).

Table 1 ILWFRC mix design

\begin{tabular}{lll}
\hline & & ILWFRC \\
\hline CEM Type II 42.5R & $\left(\mathrm{kg} / \mathrm{m}^{3}\right)$ & 265 \\
Water & $\left(\mathrm{kg} / \mathrm{m}^{3}\right)$ & 172 \\
CEG & $\left(\mathrm{kg} / \mathrm{m}^{3}\right)$ & 118 \\
GEG & $\left(\mathrm{kg} / \mathrm{m}^{3}\right)$ & 113 \\
Superplasticizer & $\left(\mathrm{kg} / \mathrm{m}^{3}\right)$ & 2.25 \\
Air entraining agent & $\left(\mathrm{kg} / \mathrm{m}^{3}\right)$ & 0.016 \\
VMA & $\left(\mathrm{kg} / \mathrm{m}^{3}\right)$ & 0.50 \\
Macro-synthetic fibres & $\left(\mathrm{kg} / \mathrm{m}^{3}\right)$ & 4.00 \\
w/b ratio & $(-)$ & 0.65 \\
Theoretical unit weight & $\left(\mathrm{kg} / \mathrm{m}^{3}\right)$ & 675 \\
\hline
\end{tabular}


GEG was obtained from selected waste glass, which was ground into a fine powder, then mixed with water and blowing agents and, finally, granulated. The resulting granules were later heat treated to obtain white, lightweight, round aggregates. CEG was obtained from waste glass, suitably deprived of organic contaminants, which was ground and mixed in a planetary mixer with foaming agents. The mixture was, then, introduced into a tunnel kiln at $1000{ }^{\circ} \mathrm{C}$ to obtain a glass foam. Finally, the material was crushed and supplied in different grain size distribution.

Synthetic fibres, with a unit weight of $910 \mathrm{~kg} / \mathrm{m}^{3}$, were adopted to not jeopardize the thermal performance of ILWFRC. A blend of polyolefin and polypropylene (fibrillated) fibres were used in a dosage of $4 \mathrm{~kg} / \mathrm{m}^{3}$ to obtain a stable post-cracking behaviour in flexure according to EN 14651 [38]. The equivalent diameter of the fibres was $0.7 \mathrm{~mm}$ and the length was $54 \mathrm{~mm}$, resulting in an aspect ratio of 80 . The tensile strength of the fibres ranged between 620 and $758 \mathrm{MPa}$, as declared by the manufacturer.

The material was produced in a ready-mix plant and delivered on site with a truck. To consider the possible crushing of lightweight aggregates during the mixing phase, the following procedure was adopted: (A) introduction of aggregates in the mixer; (B) introduction of binder and water; $(\mathrm{C})$ mixing for 15 min (truck travel); (D) introduction of admixtures and synthetic fibres; (E) final mixing for an additional $15 \mathrm{~min}$.

\subsection{Mechanical properties}

\subsubsection{Fresh state properties}

The fresh state properties were similar to those of traditional concrete. Slump was $220 \mathrm{~mm}$ at the delivery on site (30 min after water addition). Workability of ILWFRC fresh mixture suggested choosing the same technology traditionally used in concreting for the construction of walls. Vibration was not necessary due to the self-compacting property of ILWFRC.

\subsubsection{Hardened state properties}

Hardened state properties were considerably lower than those of traditional concrete (Table 2). Elastic modulus of $3 \mathrm{GPa}$ (according to EN 12390-13 [39]) and compressive strength of $3.5 \mathrm{MPa}$ (at 28 days) were in a range similar to those of hollow clay (HC) masonry or AAC masonry. However, the reduced selfweight (of about $650 \mathrm{~kg} / \mathrm{m}^{3}$ ) and the appreciable fracture toughness (relative to the low compressive strength), make ILWFRC suitable for use in the field of seismic engineering for the construction of large elements, such as walls. Table 2 also summarizes dried density and water content of ILWFRC at different ages. It is worth noting that compressive strength measured after 1 day $(2.5 \mathrm{MPa})$ was about $73 \%$ of the 28-day compressive strength. The development of strength in ILWFRC is particularly rapid in the first $24 \mathrm{~h}$, then followed by a gradual increase up to 28 days and a basically negligible development for later ages (up to 365 days).

ILWFRC in compression is characterized by a linear behaviour until reaching of compressive strength (see Fig. 1a). After the peak load (at a strain of $3 \%$ ) a sudden drop of stress was observed, and was then followed by a horizontal branch up to a strain of $5 \%$ (end of the test) with a residual strength of about $75 \%$ of the peak. The stable post-peak behaviour is mainly due to the contribution of fibres in limiting the transverse deformation.

The behaviour of ILWFRC in flexure was characterized by a linear increase of strength until reaching the flexural tensile strength (Limit of Proportionality LOP), followed by a nearly horizontal post-cracking branch (Fig. 1b).

\subsection{Thermal properties}

Thermal properties of ILWFRC have been determined after 28 days of curing. Thermal conductivity was measured to be equal to $0.111 \mathrm{~W} / \mathrm{mK}$ on a $300 \times 300 \times 30 \mathrm{~mm}$ plate specimen (according to EN 12664 [40]) placed between hot and cold plates by means of a thermal flowmeter. Vapour permeability was measured to be equal to 6 on $\varnothing 150 \times 50 \mathrm{~mm}$ cylinders (according to EN 1015-19 [41]). Specific heat of $0.461 \mathrm{~J} / \mathrm{m}^{3} \mathrm{~K}$ was measured according to an internal method by using a surface probe, which measures temperature change in a sample subjected to heating by the surface probe itself.

\subsection{Comparison with other building materials}

In order to understand the potential for the application of ILWFRC in the construction of residential and 
Table 2 Compressive strength, dried density and water content of ILWFRC: number of tests (n), mean value $(\mu)$, and standard deviation $(\sigma)$

\begin{tabular}{|c|c|c|c|c|c|c|c|c|c|c|}
\hline \multirow[t]{2}{*}{ Age from casting } & & \multirow{2}{*}{$\begin{array}{l}\text { Units } \\
\text { (days) }\end{array}$} & \multicolumn{8}{|c|}{ ILWFRC } \\
\hline & & & 1 & 4 & 7 & 14 & 21 & 28 & 42 & 365 \\
\hline \multirow[t]{3}{*}{ Compressive strength } & $\mathrm{n}$ & $(-)$ & 3 & 3 & 3 & 3 & 3 & 3 & 3 & 1 \\
\hline & $\mu$ & $(\mathrm{MPa})$ & 2.52 & 2.72 & 2.89 & 3.13 & 3.25 & 3.47 & 3.51 & 3.87 \\
\hline & $\sigma$ & $(\mathrm{MPa})$ & 0.14 & 0.27 & 0.26 & 0.35 & 0.10 & 0.44 & 0.51 & - \\
\hline \multirow[t]{3}{*}{ Dried density } & $\mathrm{n}$ & $(-)$ & 3 & 3 & 3 & 3 & 3 & 3 & 3 & 1 \\
\hline & $\mu$ & $\begin{array}{c}(\mathrm{kg} / \\
\left.\mathrm{m}^{3}\right)\end{array}$ & 647 & 611 & 636 & 636 & 616 & 643 & 605 & 625 \\
\hline & $\sigma$ & $\begin{array}{c}(\mathrm{kg} / \\
\left.\mathrm{m}^{3}\right)\end{array}$ & 18 & 33 & 31 & 8 & 20 & 27 & 12 & - \\
\hline \multirow[t]{3}{*}{ Water content } & $\mathrm{n}$ & $(-)$ & 3 & 3 & 3 & 3 & 3 & 3 & 3 & 1 \\
\hline & $\mu$ & $\begin{array}{c}(\mathrm{kg} / \\
\left.\mathrm{m}^{3}\right)\end{array}$ & 143 & 119 & 116 & 114 & 84 & 92 & 65 & 7 \\
\hline & $\sigma$ & & 3 & 11 & 4 & 5 & 10 & 11 & 3 & - \\
\hline
\end{tabular}

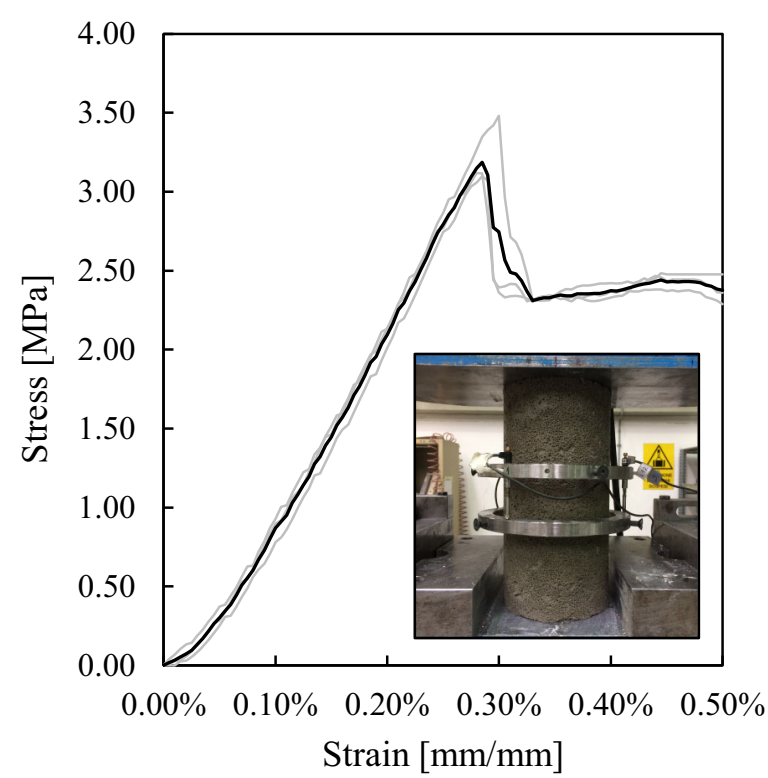

(a)

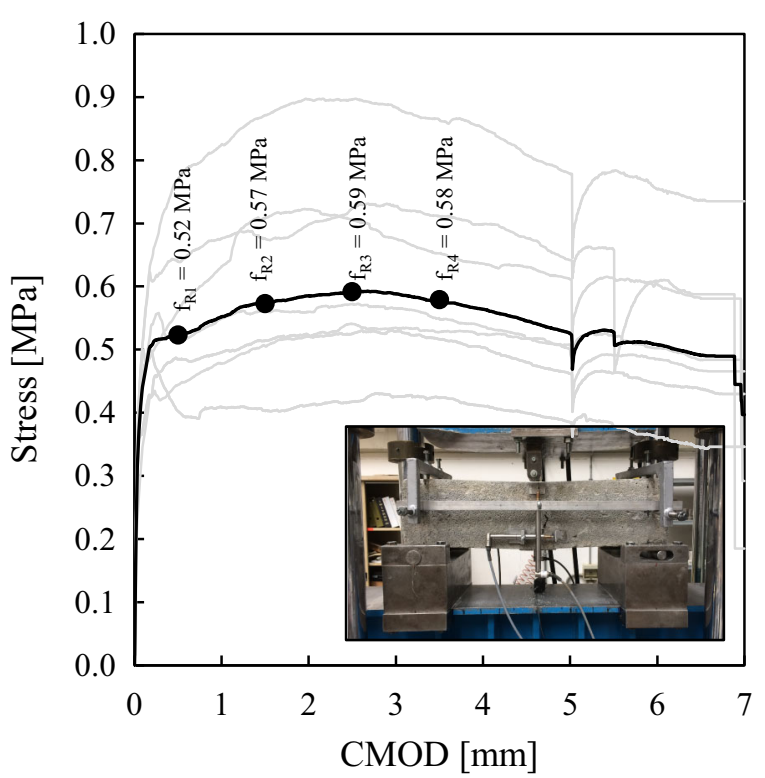

(b)

Fig. 1 Stress-strain curve of ILWFRC in compression (a) and stress-CMOD (Crack Mouth Opening Displacement) in flexure with residual tensile strength values $(\mathbf{b})$

commercial buildings, a comparison with other materials is herein outlined. The materials selected are the HC bricks masonry, which is one of the most widely used materials for the construction of infill panels (especially in southern Europe), and the AAC blocks masonry, which is the commercial material most similar, in terms of mechanical and thermal properties, to the material herein presented. The main difference between the latter and ILWFRC lies in the fact that
AAC is delivered to the construction site in blocks, while ILWFRC is a concrete that can be cast using traditional concreting techniques. It is worth noting that the execution of masonry, both with HC bricks or AAC blocks, is generally time consuming and requires skilled workers or the use of special materials, such as special mortar for AAC blocks. On the other hand, the use of ILWFRC could be more time-efficient since it does not require specialised labour or special treatments. 
The mechanical and thermal properties of typical HC bricks, AAC blocks, and ILWFRC are compared. ILWFRC is characterized by similar values of compressive strength and thermal conductivity $(3 \div 5 \mathrm{MPa}$ and $0.1 \mathrm{~W} / \mathrm{mK})$ with respect to $\mathrm{HC}$ bricks $(3 \div 5 \mathrm{MPa}$ and $0.2 \div 0.4 \mathrm{~W} / \mathrm{mK})$ [42] and to AAC blocks $(3 \div 6 \mathrm{MPa}$ and $0.09 \div 0.12 \mathrm{~W} / \mathrm{mK})[43,44]$. In addition, it should be noted that the thermal performance of masonry, both with $\mathrm{HC}$ bricks or AAC blocks, could be negatively affected by the presence of mortar/ adhesive joints between the bricks/blocks.

In order to understand how ILWFRC could be successfully used for the construction of infill panels, three different types of walls have been compared: an ILWFRC wall, a HC brick wall, and an AAC block wall. The first is composed of a single layer of ILWFRC (41 cm thick) and two plaster layers $(1.5+1.5 \mathrm{~cm}$ thick). The second wall is composed of two layers of hollow clay bricks $(10+20 \mathrm{~cm}$ thick) and an inner layer of polystyrene ( $11 \mathrm{~cm}$ thick). The external and internal surfaces are covered with plaster layers $(1.5+1.5 \mathrm{~cm}$ thick). The third wall is composed of a single layer of AAC blocks $(41 \mathrm{~cm}$ thick) and two plaster layers $(1.5+1.5 \mathrm{~cm}$ thick). The total wall thickness is equal to $44 \mathrm{~cm}$ for all three walls considered.

Thermal properties of the walls have been calculated according to Italian standards for energy efficiency. The simulation has been performed by considering a location in climatic zone E (Bergamo) characterized by a degrees-day value of 2533 , a monthly average irradiance of $259 \mathrm{~W} / \mathrm{m}^{2}$, a superficial mass limit of $230 \mathrm{~kg} / \mathrm{m}^{2}$ and a thermal transmittance limit of $0.2 \mathrm{~W} / \mathrm{m}^{2} \mathrm{~K}$. The calculated values of superficial mass and thermal transmittance of ILWFRC wall (329 kg/m ${ }^{2}$ and $\left.0.24 \mathrm{~W} / \mathrm{m}^{2} \mathrm{~K}\right), \mathrm{HC}$ brick wall (309 kg/ $\mathrm{m}^{2}$ and $\left.0.23 \mathrm{~W} / \mathrm{m}^{2} \mathrm{~K}\right)$ and AAC block wall $\left(272 \mathrm{~kg} / \mathrm{m}^{2}\right.$ and $0.22 \mathrm{~W} / \mathrm{m}^{2} \mathrm{~K}$ ) are very similar. All walls considered satisfy thermal transmittance limits and the superficial mass limit according to the Italian codes.

\section{ILWFRC application for infill walls: experimental investigation}

\subsection{Experimental program}

A full-scale experimental test was carried out on an ILWFRC infill wall subjected to both in-plane and out- of-plane actions. The wall was tested inside a steel frame designed to apply lateral in-plane deformation according to an inter-story sway mechanism of a moment resisting frame. The test included the following phases:

1. In-plane test performed on the infill wall under a horizontal cyclic load applied to the frame top beam up to a maximum drift of $4 \%$. The test was performed 42 days after the specimen preparation.

2. Out-of-plane test performed after the in-plane test, applying an increasing lateral load uniformly distributed over 8 point loads up to failure. The test was performed 49 days after the specimen preparation.

\subsection{Test set up}

The ILWFRC infill wall was $2.9 \mathrm{~m}$ long, $2.6 \mathrm{~m}$ depth and $0.2 \mathrm{~m}$ thick. The total mass of the wall was approximately 1 ton. The wall was made using a single batch of ILWFRC, poured inside the testing frame with the help of wooden formworks on both sides of the wall, leaving a gap of $2 \mathrm{~cm}$ with the frame top beam. After 3 days, the formworks were removed. After 28 days, the gap between the wall and the top beam was filled with a shrinkage compensated mortar to ensure an efficient contact between the wall and the testing frame. The metallic ties of the formworks remained inside the specimen after demoulding.

The in-plane test aimed at analysing the behaviour of an infill wall in terms of deformation capacity, stiffness, resistance and damage to several cycles of imposed deformation. The testing apparatus adopted was developed and tested by Preti et al. [34] and was designed to be reused several times. A HE260B profile was used for the base beam and HE240B profiles for the columns and the top beam (Fig. 2). The columns of the testing steel frame were hinged to the top and bottom beam to activate a kinematic mechanism, offering negligible resistance against lateral load. Therefore, lateral resistance measured during the test was assumed as the net lateral resistance of the infill. During the in-plane test, lateral displacement was imposed to the frame top beam by a hydraulic jack controlled by an electro-hydraulic system (in deformation control). The hydraulic jack was hinged to a steel frame connected to the bottom beam of the testing frame, thus creating a self-balanced system. 


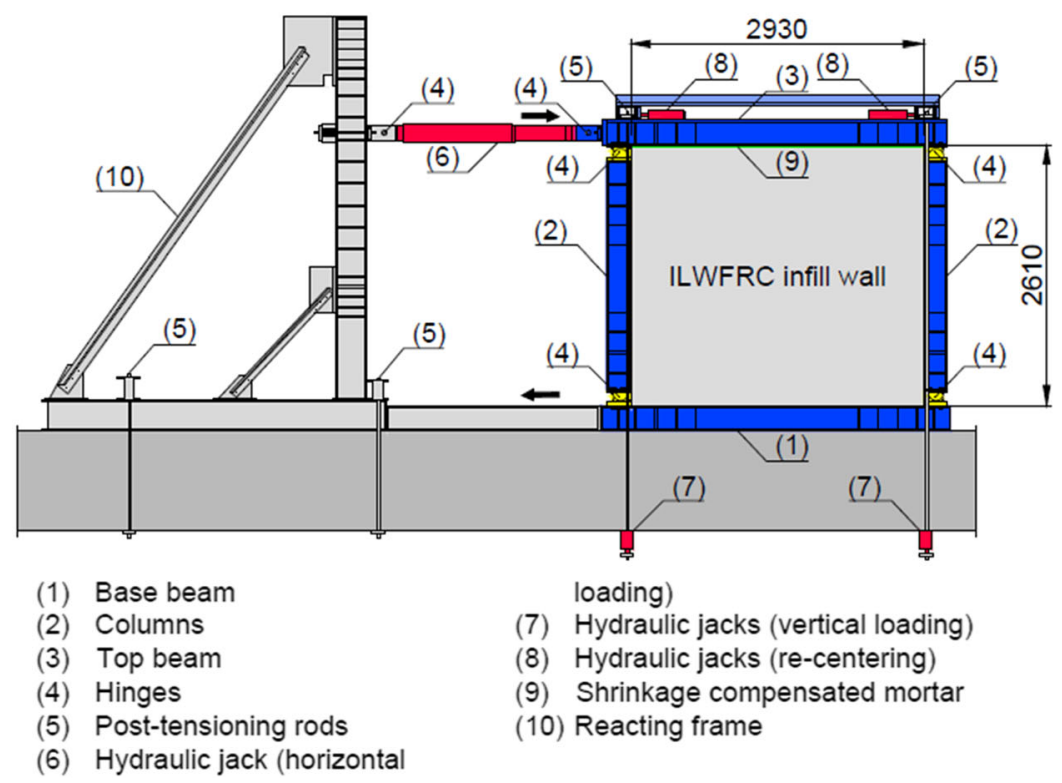

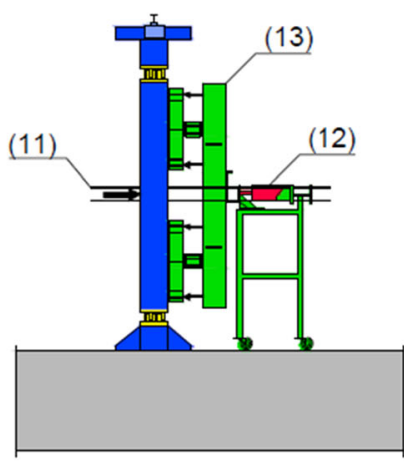

(11) Post-tensioning rods

(12) Hydraulic jack (horizontal loading)

(13) Loading frame

Fig. 2 Test setup: in-plane test and out-of-plane test (measures in millimetres)

The out-of-plane test was performed with the aim of evaluating the stability of the infill damaged by several cycles of imposed deformation, after reaching a maximum drift of $4 \%$. The out of plane load was applied at $0 \%$ in-plane drift for the specimen, after recentring the residual in-plane drift. In this condition the active confining action on the diagonal strut was considered null or limited. The out-of-plane load was applied through a hydraulic jack by using the selfbalanced system developed by Preti et al. [34] acting on 8 loading points on the wall (in load control).

The equilibrium to prevent overturning of the testing frame, both in- and out-of-plane, was given by two external prestressed rebars acting on each column and anchored at the strong floor. The external rebars provided an axial load on each column (equal to $160 \mathrm{kN}$ ), proportioned with the only intent of preventing the columns from decompression at maximum horizontal load applied to the system. They were maintained in a vertical position during the test by imposing, at each load step, a horizontal relative displacement between the rebars and steel confining frame, by means of a recentering system. The vertical load was monitored and adjusted throughout the test.

The recentering system had two purposes: on the one hand, it was necessary to prevent the rupture of the bars, which, fixed at their base, would be subject to shear force (if they were moving together with the frame); and, on the other hand, it was necessary to prevent the increase of the axial load in the bars due to their elongation with the frame movement (if they had not been recentered).

In order to consider the second order effect of vertical forces acting on the column ends, the actual response of the infill has been calculated according to Eq. (1):

$\mathrm{F}_{\mathrm{h}}=\mathrm{F}_{\mathrm{h} \text {,measured }}+\delta \cdot \mathrm{F}_{\mathrm{v}}$

where $F_{h}$ is the actual infill response, $F_{h \text {,measured }}$ is the horizontal load measured on the test frame, $\delta$ is the inter-story drift, and $F_{v}$ is the total vertical load on the test frame.

\subsection{Loading protocol}

Cyclic load reversals were applied during the in-plane test (positive and negative directions in the following) under the drift $(\delta)$ ratio-controlled protocol summarized in Fig. 3a. Increasing drift levels from $0.05 \%$ to $4 \%$ were applied for exploring the response from the Operational Limit State (OLS) to Ultimate Limit State (ULS) drift limits, later discussed in the text. During 
the out-of-plane test (see Fig. 3b), the infill wall was subjected to cyclic loading under a load-controlled protocol. Load was increased between a minimum load of $2 \mathrm{kN}$ (force equivalent to a transverse acceleration of about $0.2 \cdot \mathrm{g}$ ) and a maximum load varying from 4 to $20 \mathrm{kN}$ (about 2.g) in 9 steps. These load levels were considered as a range of design action for the infill. At the end of the cycles, load was increased up to failure of the infill.

\subsection{Instrumentation}

In the in-plane testing cyclic horizontal load was measured by means of a load cell located between the hydraulic jack and the testing frame (Fig. 4a). The inplane drift was monitored by measuring relative displacement of the top and the bottom frame beams. In order to measure the possible local detachments at the frame to infill interface, 2 potentiometric displacement transducers (per side) were positioned at the infill corners. For the measurement of shortenings/extensions of the two diagonals, 4 transducers (per side) were installed. For the measurement of the crack opening along the diagonals, 8 transducers were placed (per side), orthogonal to the diagonals.

For the out-of-plane test wire strain gages and potentiometric displacement transducers were used to monitor the out-of-plane displacements of the infill wall (Fig. 4b). Relative displacement transducers were utilized to monitor the relative slippage between the wall and the frame.

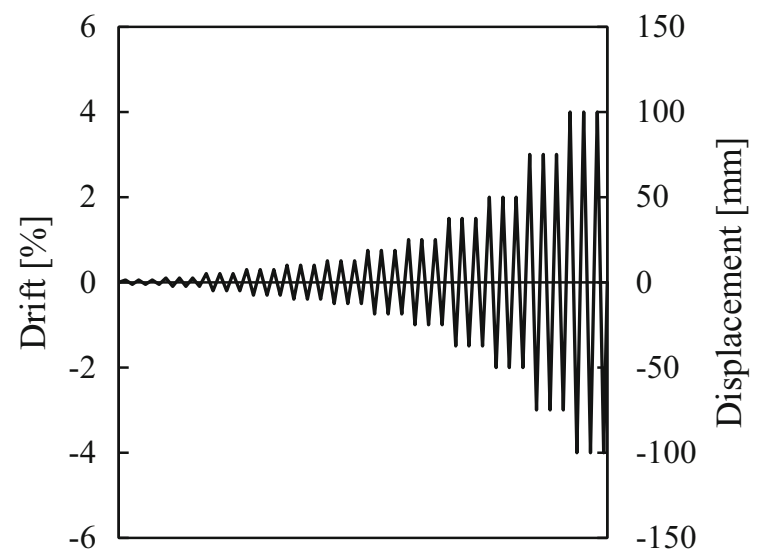

(a)

\section{Experimental results}

\subsection{In-plane test}

Figure 5 shows the quasi-static cyclic response of the infill wall during the in-plane test in terms of force vs. drift (by considering second order effects of vertical forces). Up to drift values of $0.1 \%$, the structural response was basically elastic, with limited residual deformations after unloading (Fig. 5a). Between 0.1\% and $4 \%$ drift, progressive cracking occurred and stiffness has been reduced due to the accumulation of damage in the wall. The peak lateral load was reached at $1.5 \%$ drift in both positive and negative loading direction, with a load of $359 \mathrm{kN}$ and $326 \mathrm{kN}$, respectively. The wall response was ductile with moderate strength degradation after $1.5 \%$ drift. A residual significant capacity was maintained up to large drift values: at $4 \%$ drift the load carrying capacity was $79 \%(284 \mathrm{kN})$ and $76 \%(249 \mathrm{kN})$ of the maximum load in the positive and negative direction, respectively (Fig. 5b).

The overall response of the structure was symmetrical with a pronounced pinching due to the progressive permanent deformation in the wall. Such a cumulative deformation resulted in the formation of an increasing gap between the column and the infill at the corners. In this mechanism, the top beam basically slides over the infill upper face, encountering very limited resistance until the windward column regain the infill contact.

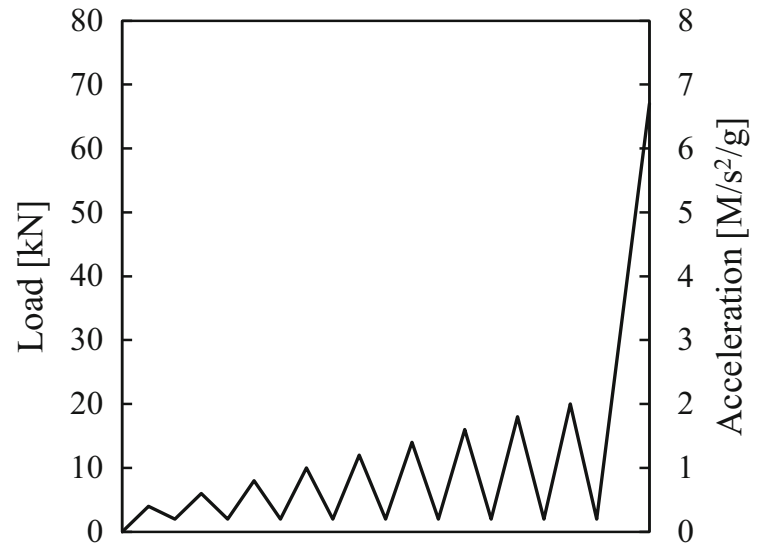

(b)

Fig. 3 Loading protocol for in-plane (a) and out of plane loading (b)

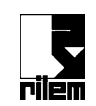




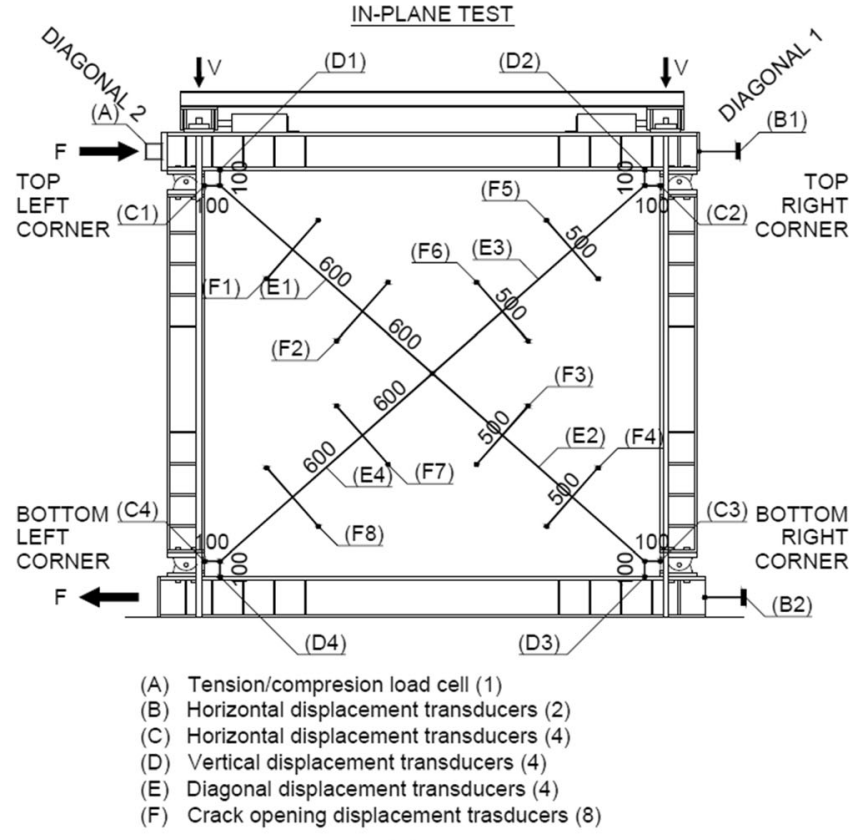

(a)
OUT-OF-PLANE TEST

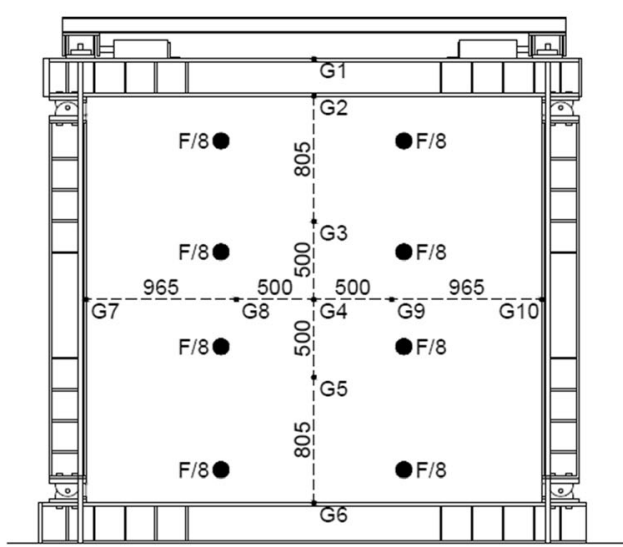

(G) Horizontal displacement transducers (10)

Fig. 4 Instrumentation for in-plane test (a) and out-of-plane test (b)

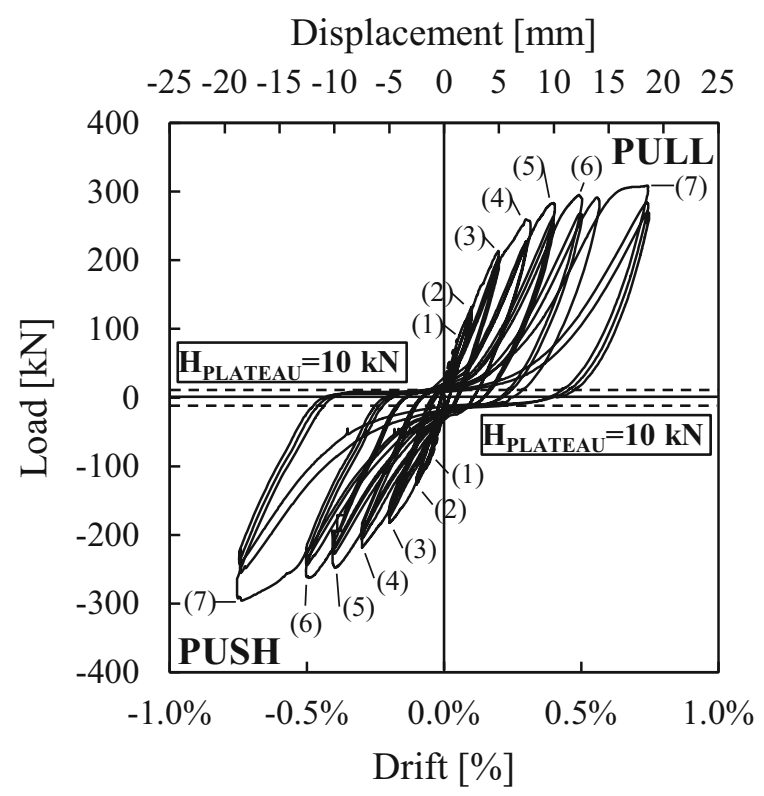

(a)

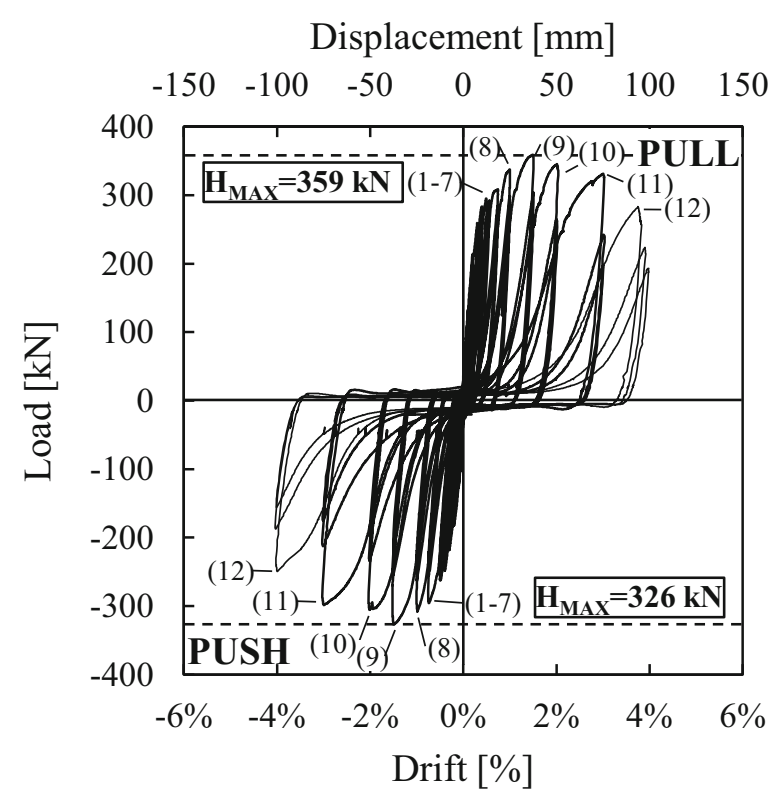

(b)

Fig. 5 In-plane response of the infill wall up to $0.75 \%$ (a) and to $4 \%$ (b) drift (cycle number in brackets)

Figure 6a shows the development of the gap between the steel column and the ILWFRC panel, as measured in the top-left corner (displacement transducer C1) and top-right corner (displacement transducer $\mathrm{C} 2$ ). The gap opening was measured in horizontal direction between the edge of the steel 
column and a reference point located on the panel, at $100 \mathrm{~mm}$ from the edge of the panel itself.

The displacement assumed negative values when the panel was pushed toward the column, due to the local compression of concrete between the column and the reference point, or positive values when the panel was moving away from the column, due to the progressive damage (i.e. crushing and cracking) occurring in the whole panel. The local concrete deformation (negative values) reached a constant value between $0.1 \mathrm{~mm}$ and $0.2 \mathrm{~mm}$ within a few cycles. The gap opening (positive values) continued to grow as the imposed drift increased, reaching a maximum value of about $3 \mathrm{~mm}$ (for drift values lower than $0.75 \%$ ). Such behaviour was observed similarly in the other corners with slightly different maximum values.

During the $0.5 \%$ drift cycle, the gap between the steel column and the ILWFRC panel reached a maximum displacement of about $3 \mathrm{~mm}$ at maximum drift and a value of about $1 \mathrm{~mm}$ at recentring.

Figure 7 illustrates the crack pattern development with sketches and pictures. Cracks were detected by visual inspection and highlighted after every cycle. A first diagonal crack was observed along diagonal 1 after cycle at $0.3 \%$ drift, while multiple cracks were observed along diagonal 2 after cycle at $0.4 \%$ drift. Cracks were inclined with an angle of about $45^{\circ}$ to the vertical. Cracks continued growing up to cycle at $1 \%$ drift, when a horizontal crack $50 \mathrm{~cm}$ below the top beam developed. Crack pattern developed completely during cycle at $1.5 \%$ drift, when the maximum capacity was reached. During this cycle, multiple diagonal cracks formed, which subdivided the wall into many concrete portions separated by cracks. After $1.5 \%$ drift, a stable failure mechanism was formed, and load bearing capacity began to decrease. The maximum cumulative crack opening, measured by local transducer F6 (about $5 \mathrm{~mm}$ ), was observed along the diagonal 1, while a maximum diagonal crack opening, of about $2 \mathrm{~mm}$, was observed along the diagonal 2 (transducer F2), as shown in Fig. 6b. After $0.2 \%$ drift the crack width along diagonal 1 grew more rapidly than along diagonal 2 , following the triggering of multiple parallel cracks.

The total deformation of the diagonal struts, in tension and in compression, was linear for both the diagonal struts up to drift level of $0.75 \%$. At this stage, the maximum deformation of the strut was reached in

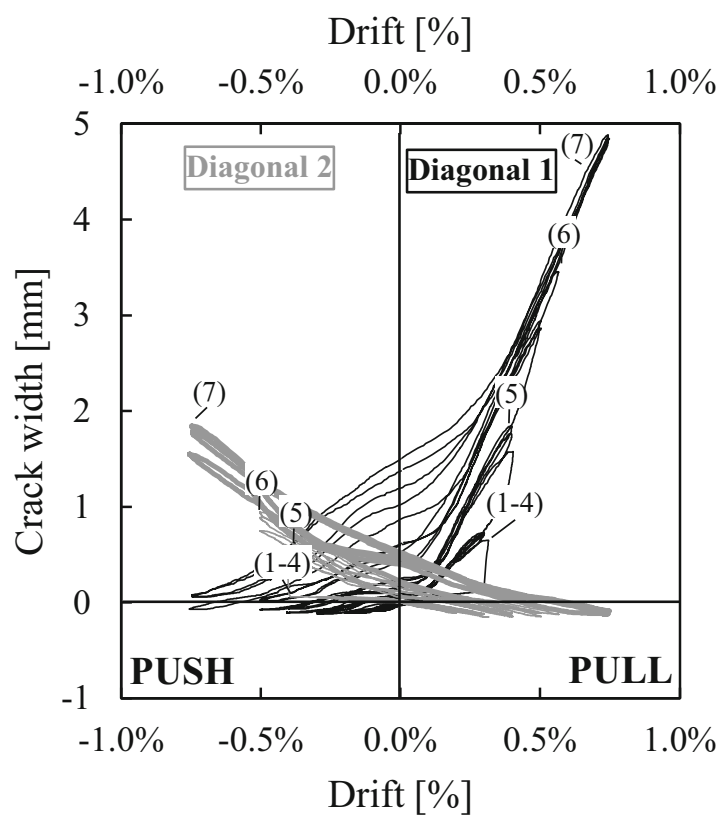

(b)

Fig. 6 Top corner horizontal column to infill gap opening versus drift (a) and crack width along the diagonals versus drift (b) (cycle number in brackets) 
Fig. 7 Crack pattern development during inplane and out-of-plane testing

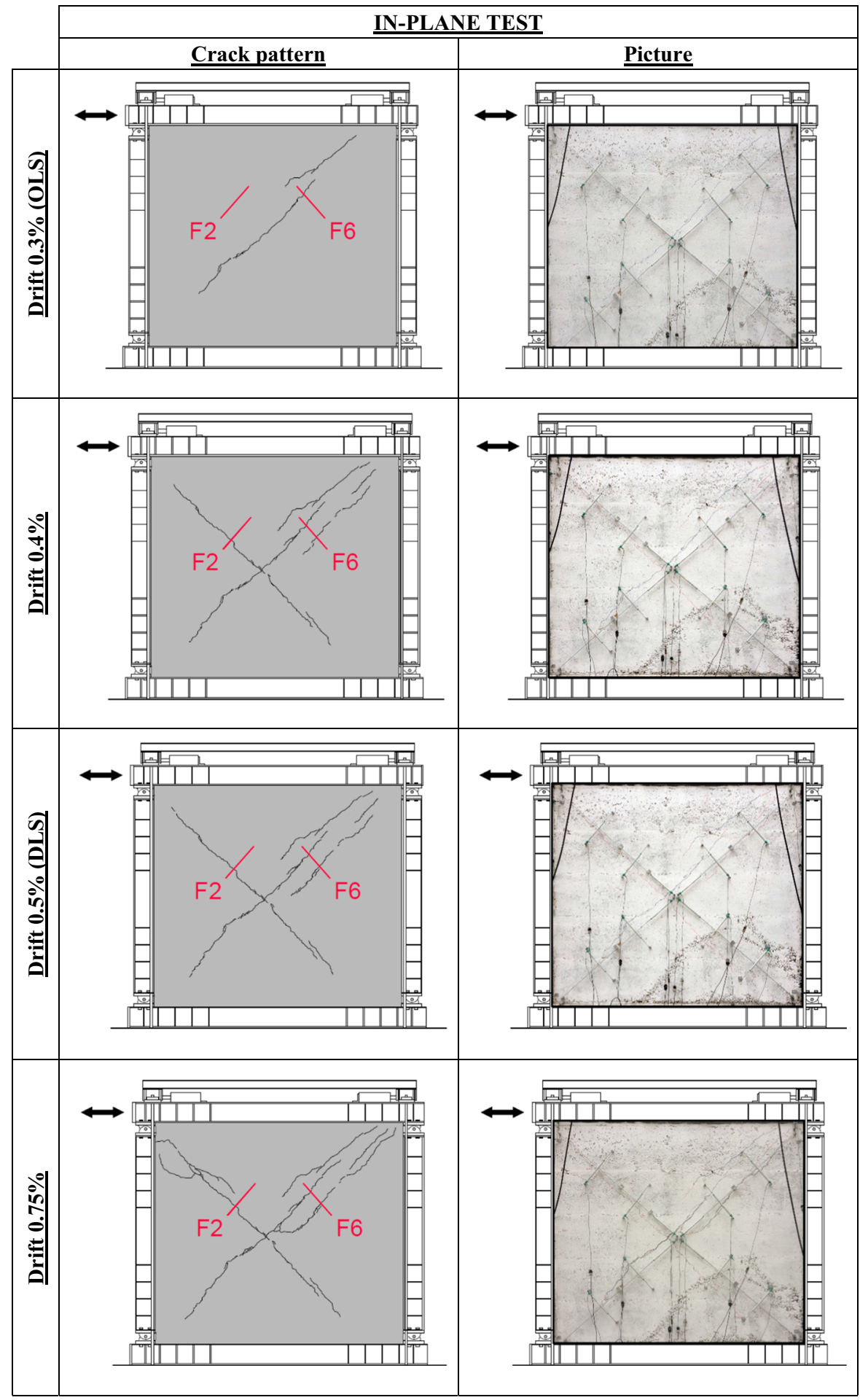


Fig. 7 continued

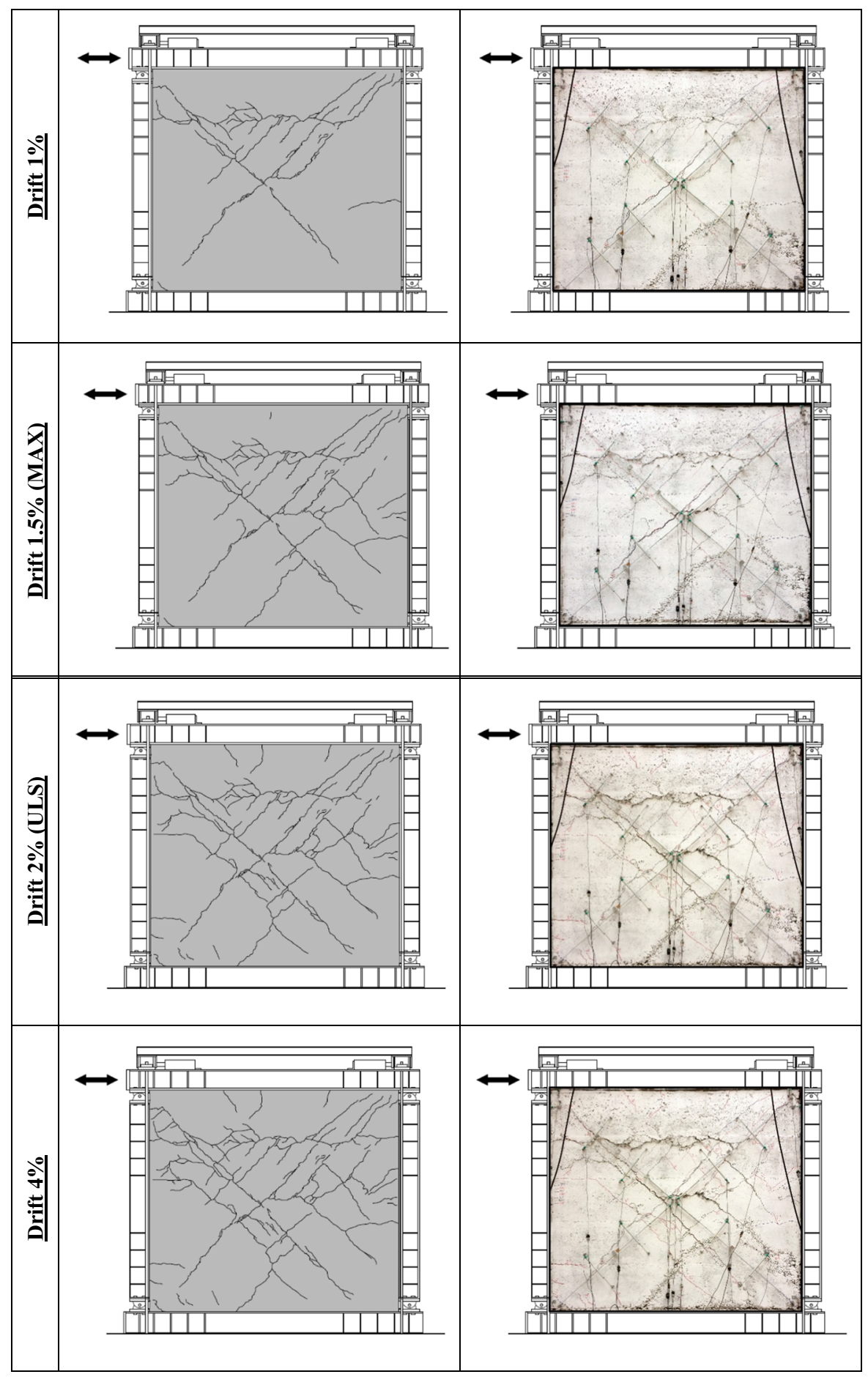


Fig. 7 continued

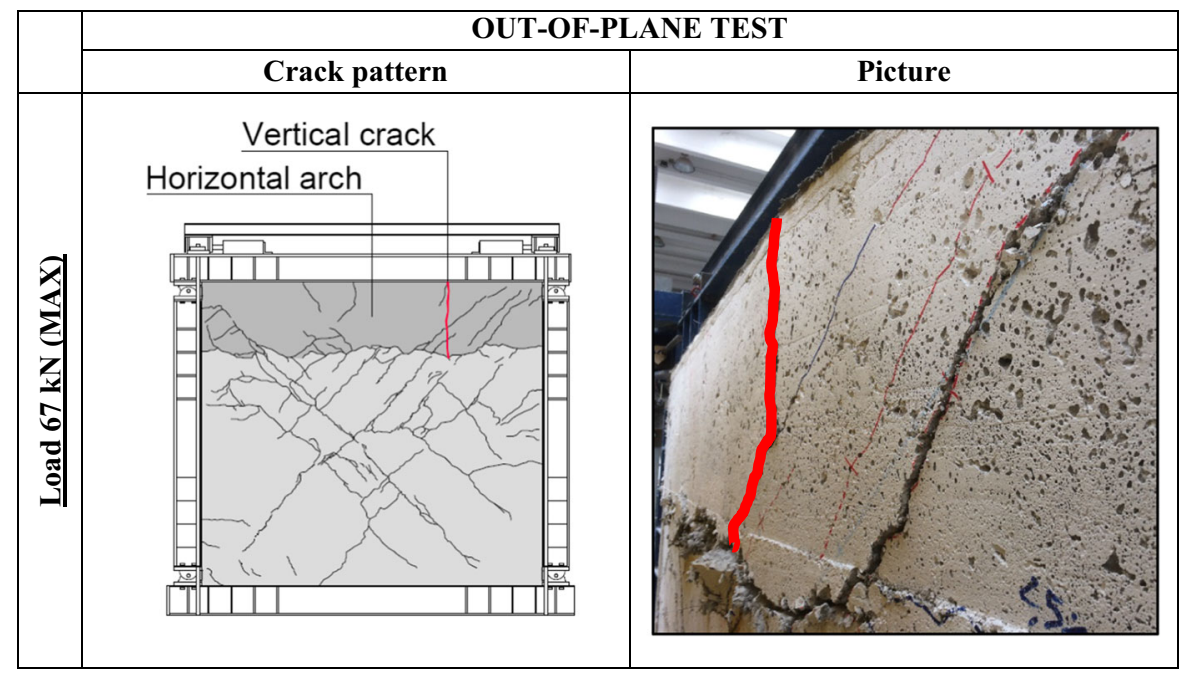

compression along the diagonal 2, with a value of about $6 \mathrm{~mm}$.

\subsection{Out-of-plane test}

Figure 8a shows the out-of-plane response of the infill wall, tested after being damaged during the in-plane test. In particular, the figure shows the lateral load versus the displacement of the point at the centre of the wall (by considering the rigid rotation of the frame). Cyclic loads of increasing amplitude were applied until reaching a horizontal force corresponding to twice the gravity acceleration (2.g); eventually, a monotonic increasing load was applied up to the maximum wall capacity (equal to, $67 \mathrm{kN}$, corresponding to an acceleration of about $7 \cdot \mathrm{g}$ ).

It should be noted that for a load higher than $30 \mathrm{kN}$ (about $3 \cdot g$ equivalent acceleration), the wall increased its stiffness. This phenomenon can be explained considering a first phase (up to $3 \cdot \mathrm{g}$ ) in which the wall was subjected to sliding outside the steel frame and a second phase (between $3 \cdot \mathrm{g}$ and $7 \cdot \mathrm{g}$ ) in which the trust of the horizontal arch mechanism, between the columns of the frame, was activated by friction. Failure was observed in the wall with the development of a vertical crack (see Fig. 7).

The deformed shape of the wall in the horizontal direction at mid-height (see Fig. 8b) and in the vertical direction at mid-span (see Fig. 8a) can be related to the development of a bi-axial resistant mechanism fully active in the horizontal direction (between the columns) and partially active in the vertical direction (since the upper edge was not effectively restrained by the top beam). A significant out-of-plane sliding occurred between the steel frame and the infill, up to values of about $20 \mathrm{~mm}$ (1/10 of the wall thickness) at the bottom and lateral edges; the sliding was larger at the top steel beam (about $40 \mathrm{~mm}, 1 / 5$ of the wall thickness). Such sliding was influenced by the gap developed at the column-infill interface during the inplane test, due to the local permanent deformation of the infill material. In order to inhibit such sliding a connection could be provided, for example, with an un-bonded shear key [45], in order to allow in-plane detachment from the infill from the column while inhibiting transverse sliding.

\section{Discussion on the experimental results}

\subsection{Stiffness degradation and energy dissipation}

Structural performances are described in terms of inplane stiffness degradation and energy dissipation capacity $\left(\xi_{\text {eq }}\right)$ in repeated cycles of increasing amplitude.

Figure 9 shows the envelope curves of the ILWFRC infill wall for the first, second and third repetition of loading at the same drift level, while Fig. 10a shows the secant stiffness calculated as the ratio between the lateral load $\left(\mathrm{F}_{\Delta \max }\right)$ and peak displacement $\left(\mathrm{d}_{\Delta \max }\right)$ reached during each cycle. During the first cycle at 


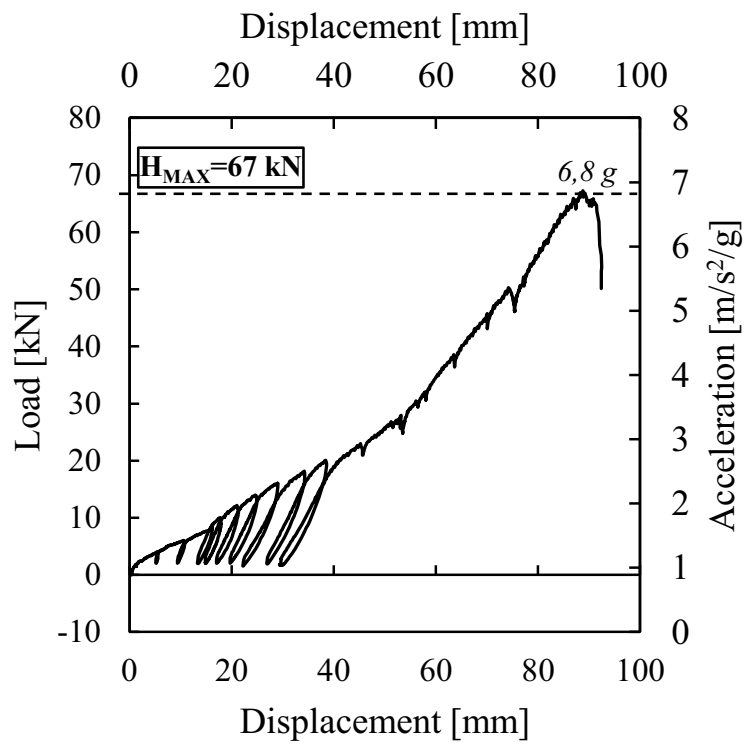

(a)

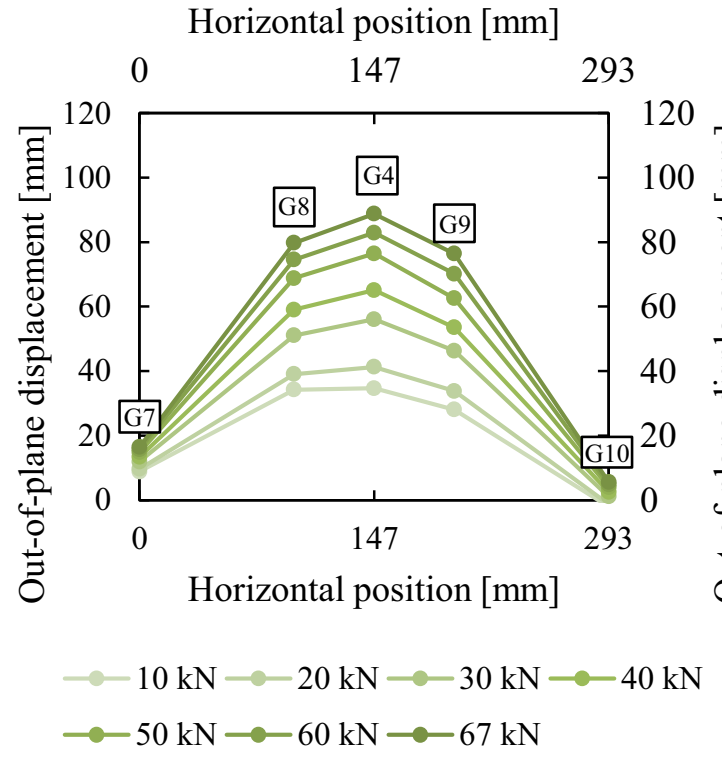

(b)
Out-of-plane displacement [mm]
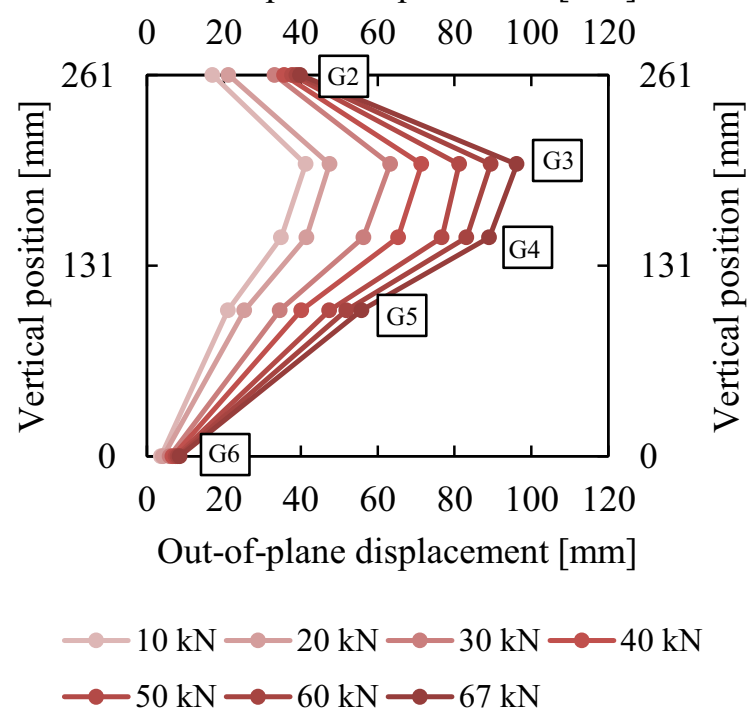

(c)

Fig. 8 Out-of-plane response of the infill wall: load versus displacement curve (a), horizontal profile of deflection at the infill midheight (b) and vertical profile of deflection at the infill mid-span (c)

$0.05 \%$ drift, the initial stiffness showed an average (positive and negative loading) value of $67 \mathrm{kN} / \mathrm{mm}$. In the following cycles, the secant stiffness continued decreasing, halving the value at $0.3 \%$ drift and reaching a value equal to one twentieth $(1 / 20)$ at $4 \%$ drift. Figure 10a shows also the values of the secant stiffness for the second and third cycles at the same amplitude, which result slightly lower than that of the first cycles.

Concerning the energy dissipation capacity of the infill, the equivalent viscous damping coefficient $\left(\xi_{\text {hys }}\right)$ was calculated by means of Eq. (2), considering the total dissipated energy $\left(\mathrm{E}_{\mathrm{hys}}\right)$, as the sum of the areas enclosed in the single hysteretic loop $\left(\mathrm{W}_{\mathrm{d}}\right)$, and 


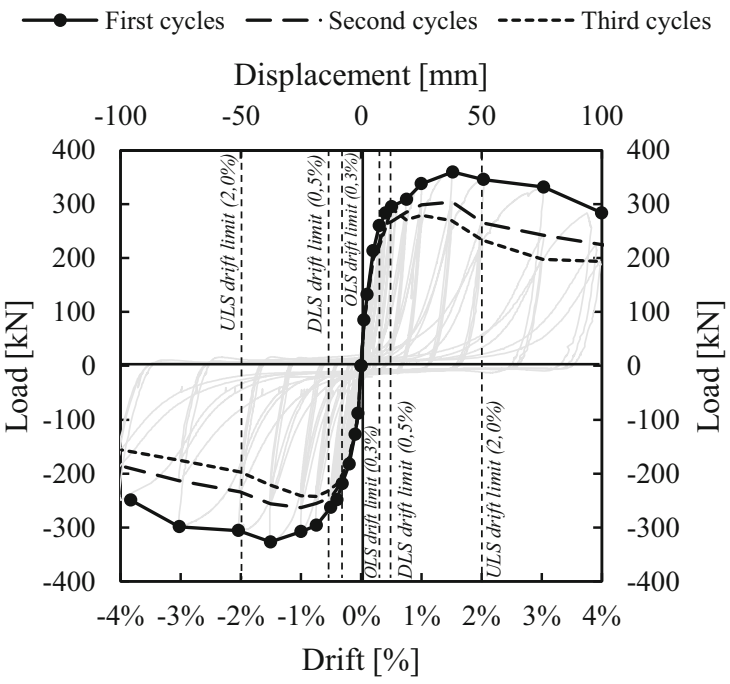

Fig. 9 Envelope curves: first cycles, second cycles, and third cycles

the elastic energy stored in the sample at peak displacement in the same loop $\left(\mathrm{W}_{\mathrm{e}}\right)[10]$.

$\xi_{e q}=\frac{W_{d}}{2 \pi\left(\left|W_{e}^{+}\right|+\left|W_{e}^{-}\right|\right)}$

Considering the first cycle of loading at the selected drift amplitude, the equivalent viscous damping
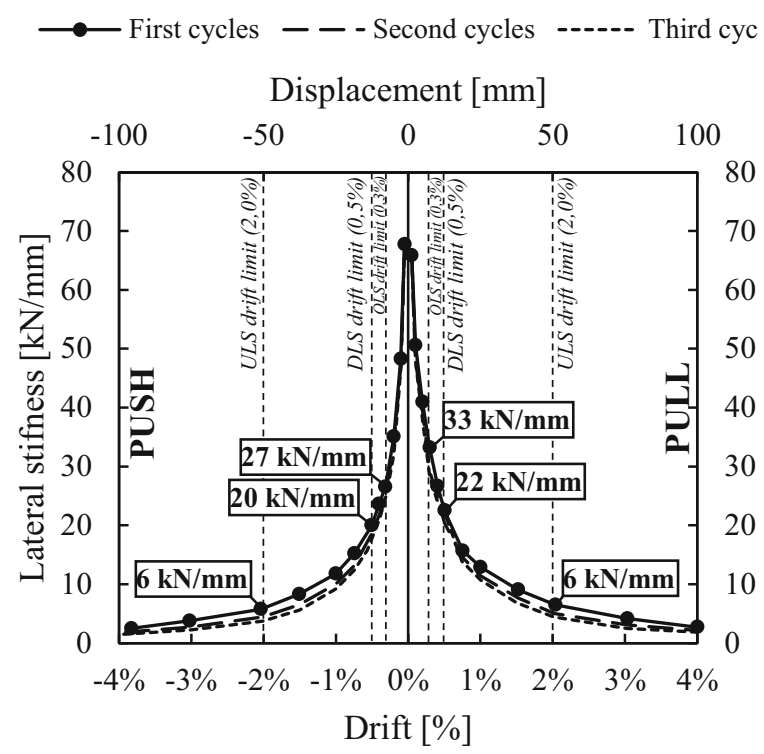

(a) coefficient $\left(\xi_{\text {hys }}\right)$ increased from $6 \%$ at $0.1 \%$ drift to $16 \%$ at $3 \%$ drift with an overall stable behaviour. At $4 \%$ drift a decrease of the damping coefficient to $9 \%$ was observed, due to the significant reduction of dissipative capacity of the infill. In the following two cycles, a less variable trend was observed, with a minimum value of $6 \%$ at $0.1 \%$ drift (both for the second and the third repetition of imposed drift) and a maximum value of $9 \%$ at $2 \%$ of drift (for the third repetition).

\subsection{Performance levels}

Performance levels for the in-plane response of the ILWFRC infill wall in terms of damage pattern are identified and related to selected drift limits. Three limit states, based on the progressive damage of the ILWFRC infill wall under in-plane loading, have been defined by Morandi et al. [10] for masonry infill walls and are herein adapted for ILWFRC infill walls:

- Operational Limit State (OLS). The infill is slightly damaged. The detachment of the infill panel at the level of the top beam and near the upper part of the columns is characterized by very light and superficial cracking. A limited damage is observed without the need of repair.

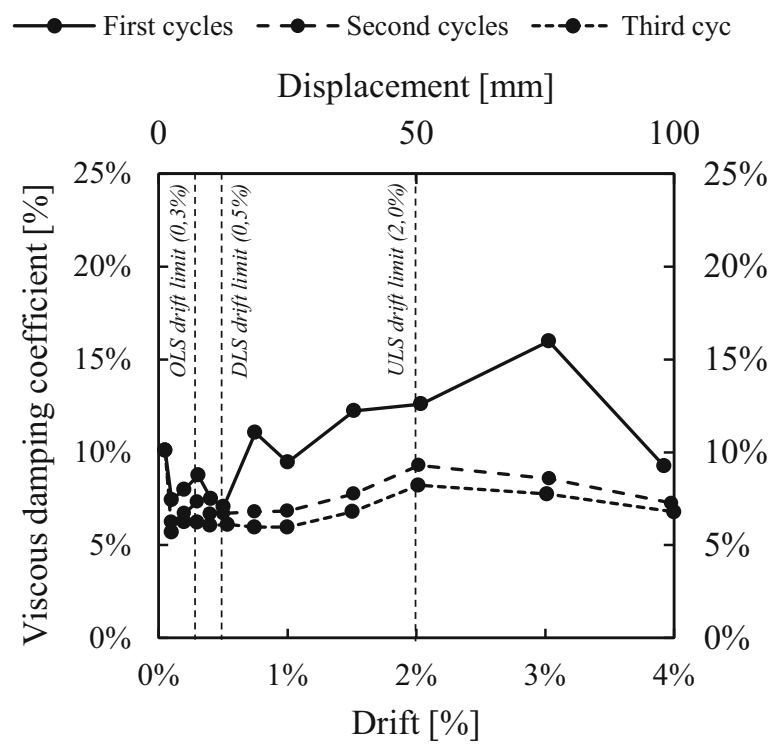

(b)

Fig. 10 Evolution of Lateral secant stiffness at peak displacement (a) and Equivalent viscous damping coefficient (b) with inter-story drift 
- Damage limitation Limit State (DLS). The infill is damaged but it can be effectively and economically repaired. The infill is characterized by bidiagonal cracking. Limited local damage occurs, for instance at the upper corner or at the top edge of the infill panel.

- Life Safety (Ultimate Limit State) (ULS). The infill is severely damaged and the repair is difficult or expensive. The infill is characterized by diffuse cracking with partitioning of the wall in a number of different units. However, stability of infill units (especially for out-of-plane loading) does not put inhabitants' safety at risk.

Thereafter, it is possible to correlate the three performance levels previously defined with selected values of drift for which a specific damage state in the ILWFRC infill wall was attained during the experimental test:

- Operational Limit State at 0.3\% drift. OLS has been identified with the detachment of the infill panel from the testing frame at the level of the top beam and near the upper part of the columns, with the gap between the wall panel and the frame at the upper corners reaching values of about $1 \mathrm{~mm}$. Limited cracking appeared on a diagonal, with a mean crack width of about $0.5 \mathrm{~mm}$. At this stage, the damage can be easily repaired given that the specimen showed a lateral load $\left(\mathrm{F}_{\mathrm{OLS}}\right)$ of about $72 \%$ (on the ascending branch) of the maximum load $\left(\mathrm{F}_{\max }\right)$. The secant stiffness at maximum displacement $\left(\mathrm{k}_{\mathrm{OLS}}\right)$ was reduced to about $50 \%$ with respect to the initial stiffness $\left(\mathrm{k}_{\mathrm{EL}}\right)$, while the equivalent viscous damping coefficient $\left(\xi_{\text {hys }}\right)$ was $8 \%$.

- Damage limitation Limit State at $0.5 \%$ drift. DLS has been identified with the complete formation of a bi-diagonal cracks, with mean crack widths smaller than $1.5 \mathrm{~mm}$ (thus having a considerable residual tensile strength as shown in Fig. 1b). Little damage was observed near the corners, with gap opening reaching values about $3 \mathrm{~mm}$. At this stage, the damage can be repaired given that the lateral load $\left(\mathrm{F}_{\mathrm{DLS}}\right)$ was about $82 \%$ (on the ascending branch) of the maximum load $\left(\mathrm{F}_{\max }\right)$ and no out-ofplane vulnerability is induced, so no strengthening interventions are required. The secant stiffness at maximum displacement $\left(\mathrm{k}_{\mathrm{DLS}}\right)$ was reduced to $22 \%$ of the initial stiffness $\left(\mathrm{k}_{\mathrm{EL}}\right)$, while the equivalent viscous damping coefficient $\left(\xi_{\text {hys }}\right)$ remained constant (about 7\%).

- Life Safety Limit State at 2\% drift. ULS has been identified with the complete partitioning of the wall in a number of different units due to a widespread diagonal cracking, however without risk of out of plane overturning. Mean crack widths were larger than $5 \mathrm{~mm}$ and gap opening larger than $10 \mathrm{~mm}$. At this stage, the peak lateral load $\left(\mathrm{F}_{\mathrm{ULS}}\right)$ drift was exceeded and a residual strength capacity was about $96 \%$ of the maximum load $\left(\mathrm{F}_{\max }\right)$. The secant stiffness at maximum displacement $\left(\mathrm{k}_{\mathrm{ULS}}\right)$ was reduced to $10 \%$ of the initial stiffness $\left(\mathrm{k}_{\mathrm{EL}}\right)$. The calculated equivalent viscous damping coefficient $\left(\xi_{\text {hys }}\right)$ increased to $10 \%$.

It is worth noting that the drift limits here proposed are conservatively based on the width and on the layout of cracks in analogy with traditional unreinforced clay masonry infills. However, the toughness of the material would allow one to consider larger drift limits (associated to operational and damage limit states) after the consideration of the stability of stress transfer across the cracks. Residual tensile strength of cracked ILWFRC is probably responsible for the shift of the peak of the in-plane infill response to a very large $1.5 \%$ drift. This aspect requires further research on the role of the material toughness on the damage repairing request.

Table 3 summarizes the performance levels of the ILWFRC infill wall under in-plane loading, the drift limits, the damage indicators and the structural performances.

\subsection{Comparison with other construction techniques}

The structural response to in-plane actions is finally compared with that of other tests carried out with the same test apparatus by other authors. Figure 11 presents the backbone curves of the test herein presented (ILWFRC) and five other tests carried out on different materials, such as solid clay masonry (SCM1 [34] and SCM2 [46]) and earthen masonry (EM [46]) infills, or different solutions to reduce infillstructure interaction, namely horizontal sliding joints masonry (HJM [45]) and vertical sliding joints masonry (VJM [47]) infills. The structural response of ILWFRC infill is characterized by an initial 
Table 3 Performance levels of the ILWFRC infill wall under in-plane loading: operational limit state (OLS), damage limitation limit state (DLS), and life safety limit state (ULS)

\begin{tabular}{|c|c|c|c|c|}
\hline Limit state & LS & $\begin{array}{l}\text { Operational limit state } \\
\text { (OLS) }\end{array}$ & $\begin{array}{l}\text { Damage limitation limit state } \\
\text { (DLS) }\end{array}$ & Life safety limit state (ULS) \\
\hline Drift & $\delta_{\mathrm{LS}}$ & $\delta_{\mathrm{OLS}}=0.3 \%$ & $\delta_{\mathrm{DLS}}=0.5 \%$ & $\delta_{\mathrm{ULS}}=2 \%$ \\
\hline \multirow[t]{3}{*}{ Damage indicators } & $\begin{array}{l}\text { Crack } \\
\text { pattern }\end{array}$ & 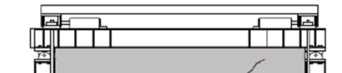 & ता & III圆 \\
\hline & Gap & $\approx 1 \mathrm{~mm}$ & $\approx 3 \mathrm{~mm}$ & $\approx 10 \mathrm{~mm}$ \\
\hline & $\begin{array}{l}\text { Crack } \\
\text { width }\end{array}$ & $\approx 0.5 \mathrm{~mm}$ & $\approx 1.5 \mathrm{~mm}$ & $\approx 5 \mathrm{~mm}$ \\
\hline \multirow{3}{*}{$\begin{array}{l}\text { Structural } \\
\text { performances }\end{array}$} & $\mathrm{F}_{\mathrm{LS}} / \mathrm{F}_{\max }$ & $\mathrm{F}_{\mathrm{OLS}} / \mathrm{F}_{\max }=72 \%$ & $\mathrm{~F}_{\mathrm{DLS}} / \mathrm{F}_{\max }=82 \%$ & $\mathrm{~F}_{\mathrm{ULS}} / \mathrm{F}_{\max }=96 \%$ \\
\hline & $\mathrm{k}_{\mathrm{LS}} / \mathrm{k}_{\mathrm{EL}}$ & $\mathrm{k}_{\mathrm{OLS}} / \mathrm{k}_{\mathrm{EL}}=50 \%$ & $\mathrm{k}_{\mathrm{DLS}} / \mathrm{k}_{\mathrm{EL}}=22 \%$ & $\mathrm{k}_{\mathrm{ULS}} / \mathrm{k}_{\mathrm{EL}}=10 \%$ \\
\hline & $\xi_{\text {hys, LS }}$ & $\xi_{\text {hys, OLS }}=8 \%$ & $\xi_{\text {hys, DLS }}=7 \%$ & $\xi_{\text {hys, ULS }}=10 \%$ \\
\hline
\end{tabular}

Fig. 11 Comparison of the Load vs. drift of different tests performed in the same frame: solid clay masonry (SCM), horizontal sliding joints masonry (HJM), vertical sliding joints masonry (VJM), earthen masonry (EM) and ILFWC infill

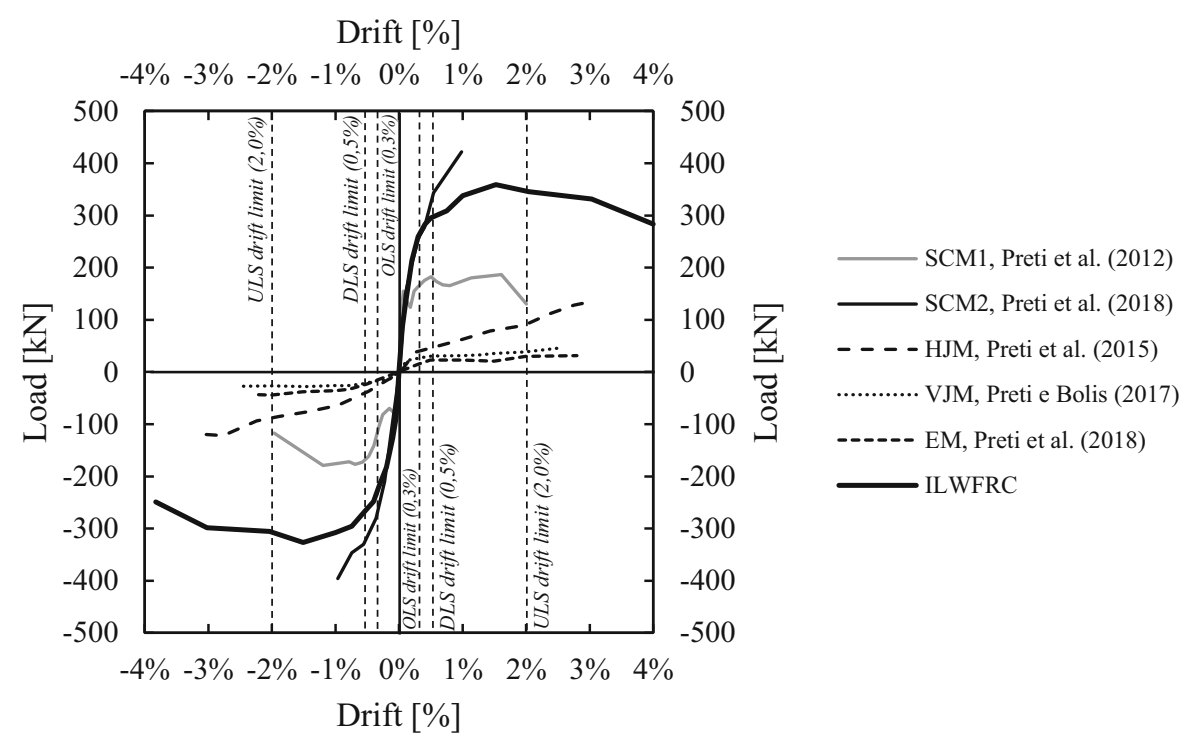

stiffness similar to that of the two solid clay masonry infills (SCM1 and SCM2) along with a load bearing capacity comparable to that of SCM2 infill, since test on SCM1 infill was characterized by shear sliding along bed joints which resulted in reduced resistance to in-plane loading. The ductility of the ILWFRC infill is markedly increased, as compared to traditional solid clay masonry. The former is characterized by a stable softening behaviour reaching $4 \%$ drift with $75 \%$ of its maximum load bearing capacity. A load equal to $85 \%$ of maximum load bearing capacity, conventionally identified as ULS for a structural element, was reached at $3.5 \%$ drift; such capacity of large in-plane displacement is similar to that of the 
other three tests presented, namely EM, HJM and VJM, but with a greater contribution to lateral resistance. In conclusion, the behaviour of ILWFRC infill was a hybrid behaviour between that of a traditional masonry wall, with high initial stiffness and high resistance, and that of solutions aimed at reducing the infill-frame interaction, with high displacement capacity. This result suggests evaluating in the future the effect of the contribution of ILWFRC infill panels to the lateral resistance of real RC infilled frame structures, quantifying the overall resistance of buildings taking into account the ILWFRC panel strength and ductility.

\section{Concluding remarks}

Based on the experimental results herein presented concerning the seismic behaviour of an infill wall made of ILWFRC, the following conclusions can be drawn:

1. Thermal characteristics of ILWFRC ensure energy performance meeting the requirements of current standards for high quality buildings. In addition, concrete is composed of $70 \%$ by volume of recycled glass aggregates and can be, in turn, recycled to become lightweight aggregates. The composition of ILWFRC, characterized by a low amount of cement $\left(265 \mathrm{~kg} / \mathrm{m}^{3}\right)$, could be further enhanced by means of alternative cementitious materials such as fly ash or slag as partial substitution of cement.

2. ILWFRC is characterized by a unit weight of about $650 \mathrm{~kg} / \mathrm{m}^{3}$, with compressive strength equal to $3.5 \mathrm{MPa}$ and elastic modulus equal to $3 \mathrm{GPa}$. The material is characterized by a stable post cracking behaviour, due to presence of synthetic fibres $(0.44 \%$ by volume), which do not influence the thermal properties of the material.

3. ILWFRC infill wall has good overall behaviour for in-plane loading, characterized by a dissipative behaviour and considerable load bearing capacity, even for high values of drift (4\%), when more than $75 \%$ of the maximum load is still present. The maximum load capacity $(359 \mathrm{kN})$ is reached at a drift of $1.5 \%$. The overall response is characterized by a marked pinching determined by the progressive compaction of the material of the wall and the consequent sliding of the top beam at loading reversal.

4. Lateral secant stiffness evolution with inter-story drift was characterized by a rapid decrease, reaching a reduction of $50 \%$ at only $0.3 \%$ drift. Energy dissipation capacity, quantified in terms of equivalent viscous damping coefficient, was characterized by values increasing form $6 \%$ at $0.1 \%$ drift to $12 \%$ at $3 \%$ drift, with an overall stable behaviour.

5. ILWFRC infill wall has a very good behaviour for out-of-plane loading, with a maximum lateral loading of $67 \mathrm{kN}$, corresponding to the inertial force associated with a lateral acceleration of about $7 \cdot \mathrm{g}$.

6. Operational limit state has been defined at $0.3 \%$ drift, with the detachment of the infill panel from the testing frame and a limited cracking of the infill. Damage limitation Limit State has been defined at $0.5 \%$ drift, with the complete formation of bi-diagonal cracks and increasing damage near the corners. Life Safety Limit State has been defined at $2 \%$ drift, with the complete partitioning of the wall in a number of different units. Such drift limits, conservatively defined based on crack pattern layout in analogy with traditional clay masonry infills, could be increased after a better understanding of the role of the material toughness on the required damage repairing intervention in further studies.

7. Out-of-plane stability has been guaranteed up to high levels of seismic action without the use of additional restraining elements. The properties of the material, among which toughness provided to concrete by fibres plays an important role, allow the infill to develop an effective biaxial out-ofplane response.

8. When compared to other construction techniques, the in-plane response of the ILWFRC infill wall is characterised by a hybrid behaviour with a high initial stiffness and high resistance, similar to traditional masonry walls made of clay units, coupled with a high displacement capacity, similar to innovative solutions able to reduce infillframe interaction.

Acknowledgements The authors wish to express their gratitude and sincere appreciation to Italcementi HEIDELBERG Cement Group and, in particular, to Dr. 
Enrico Borgarello and Ing. Massimo Borsa for supporting this research work. A special thank goes to Eng. Enrico Tignonsini, Eng. Luca Cominoli, Mr. Augusto Botturi, Mr. Domenico Caravaggi, Mr. Domenico Fiorillo, and Mr. Andrea Del Barba for their support in carrying out the experimental program.

Funding Open access funding provided by Università degli Studi di Brescia within the CRUI-CARE Agreement.

\section{Compliance with ethical standards}

Conflict of interest The authors declare that they have no conflict of interest.

Open Access This article is licensed under a Creative Commons Attribution 4.0 International License, which permits use, sharing, adaptation, distribution and reproduction in any medium or format, as long as you give appropriate credit to the original author(s) and the source, provide a link to the Creative Commons licence, and indicate if changes were made. The images or other third party material in this article are included in the article's Creative Commons licence, unless indicated otherwise in a credit line to the material. If material is not included in the article's Creative Commons licence and your intended use is not permitted by statutory regulation or exceeds the permitted use, you will need to obtain permission directly from the copyright holder. To view a copy of this licence, visit http://creativecommons.org/licenses/by/4.0/.

\section{References}

1. European Commission (2003) Directive 2002/91/EC. Off. J. Eur. Union 65-71

2. European Commission (2008) Directive 2008/98/EC. Off. J. Eur. Union 3-30

3. Cangiano S, Morbi A (2014) Dry cement mix for forming light concretes with low thermal conductivity, and concretes thus obtained, United States Patent, Patent No.: US 8,663,386 B2, Date of Patent: Mar. 4, 2014

4. Fardis MN (2006) Seismic design issues for masonry-infilled RC frames. In: 1st European conference on earthquake engineering and seismology. Geneva, Switzerland

5. (2004) Eurocode 8: design of structures for earthquake resistance-Part 1: General rules, seismic actions and rules for buildings. Eur. Comm. Norm. Brussels

6. Calvi GM, Bolognini D (2001) Seismic response of reinforced concrete frames infilled with weakly reinforced masonry panels. J Earthq Eng 5:153-185. https://doi.org/10. 1080/13632460109350390

7. Cheng X, Zou Z, Zhu Z et al (2020) A new construction technology suitable for frame partitioned infill walls with sliding nodes and large openings: test results. Constr Build Mater. https://doi.org/10.1016/j.conbuildmat.2020.119644

8. Lu X, Yang Z, Chea C, Guan H (2020) Experimental study on earthquake-induced falling debris of exterior infill walls and its impact to pedestrian evacuation. Int J Disaster Risk Reduct. https://doi.org/10.1016/j.ijdrr.2019.101372
9. Paulay T, Priestley MJN (1992) Seismic design of reinforced concrete and masonry buildings, ISBN: 978-0471-54915-4

10. Morandi P, Hak S, Magenes G (2018) Performance-based interpretation of in-plane cyclic tests on $\mathrm{RC}$ frames with strong masonry infills. Eng Struct 156:503-521. https://doi. org/10.1016/j.engstruct.2017.11.058

11. Da Porto F, Guidi G, Dalla Benetta M, Verlato N (2013) Combined in-plane/out-of-plane experimental behaviour of reinforced and strengthened infill masonry walls. In: 12th Canadian masonry symposium. Vancouver, British Coloumbia, Canada, pp 1-11

12. Milanesi RR, Morandi P, Magenes G (2018) Local effects on RC frames induced by AAC masonry infills through FEM simulation of in-plane tests. Bull Earthq Eng. https:// doi.org/10.1007/s10518-018-0353-5

13. Cavaleri L, Di Trapani F, Asteris PG, Sarhosis V (2017) Influence of column shear failure on pushover based assessment of masonry infilled reinforced concrete framed structures: a case study. Soil Dyn Earthq Eng. https://doi. org/10.1016/j.soildyn.2017.05.032

14. Preti M, Bolis V, Stavridis A (2019) Seismic infill-frame interaction of masonry walls partitioned with horizontal sliding joints: analysis and simplified modeling. J Earthq Eng. https://doi.org/10.1080/13632469.2017.1387195

15. Marques R, Lourenço PB (2019) Structural behaviour and design rules of confined masonry walls: review and proposals. Constr Build Mater. https://doi.org/10.1016/j. conbuildmat.2019.04.266

16. Najafgholipour MA, Maheri MR, Lourenço PB (2013) Capacity interaction in brick masonry under simultaneous in-plane and out-of-plane loads. Constr Build Mater. https:// doi.org/10.1016/j.conbuildmat.2012.08.032

17. Ricci P, Di Domenico M, Verderame GM (2018) Empiricalbased out-of-plane URM infill wall model accounting for the interaction with in-plane demand. Earthq Eng Struct Dyn. https://doi.org/10.1002/eqe.2992

18. Furtado A, Rodrigues H, Arêde A, Varum H (2016a) Experimental evaluation of out-of-plane capacity of masonry infill walls. Eng Struct. https://doi.org/10.1016/j. engstruct.2015.12.013

19. Furtado A, Rodrigues H, Arêde A, Varum H (2016b) Simplified macro-model for infill masonry walls considering the out-of-plane behaviour. Earthq Eng Struct Dyn. https://doi. org/10.1002/eqe. 2663

20. Furtado A, Rodrigues H, Arêde A, Varum H (2018) Out-ofplane behavior of masonry infilled RC frames based on the experimental tests available: a systematic review. Constr Build Mater

21. Milanesi RR, Morandi P, Penna A, Magenes G (2018) Seismic performance of AAC masonry infill: from traditional systems to innovative solutions. ce/papers. https://doi. org/10.1002/cepa.889

22. Zhao B, Taucer F, Rossetto T (2009) Field investigation on the performance of building structures during the 12 May 2008 Wenchuan earthquake in China. Eng Struct 31(8):1707-1723

23. Baird A, Tasligedik AS, Palermo A, Pampanin S (2014) Seismic performance of vertical nonstructural components in the 22 February 2011 Christchurch earthquake. Earthq Spectra 30(1):401-425 
24. Miranda E, Mosqueda G, Retamales R, Pekcan G (2012) Performance of nonstructural components during the 27 February 2010 Chile earthquake. Earthq Spectra 10(1193/ 1):4000032

25. Braga F, Manfredi V, Masi A et al (2011) Performance of non-structural elements in RC buildings during the L'Aquila, 2009 earthquake. Bull Earthq Eng. https://doi. org/10.1007/s10518-010-9205-7

26. Morandi P, Milanesi RR, Magenes G (2018) Innovative solution for seismic-resistant masonry infills with sliding joints: in-plane experimental performance. Eng Struct. https://doi.org/10.1016/j.engstruct.2018.09.018

27. Perry C, Phipps M, Hortacsu A (2009) Reducing the risks of nonstructural earthquake damage. In: Improving the seismic performance of existing buildings and other structuresproceedings of 2009 ATC and SEI conference on improving the seismic performance of existing buildings and other structures

28. Nasiri E, Liu Y (2016) Experimental study of the effect of interfacial gaps on the in-plane behaviour of masonry infilled RC frames. In: Brick and Block Masonry: trends, innovations and challenges-proceedings of the 16th international brick and block masonry conference, IBMAC 2016

29. Markulak D, Radić I, Sigmund V (2013) Cyclic testing of single bay steel frames with various types of masonry infill. Eng Struct. https://doi.org/10.1016/j.engstruct.2013.01.026

30. Pallarés FJ, Pallarés L (2016) Experimental study on the response of seismically isolated masonry infilled steel frames during the initial stages of a seismic movement. Eng Struct. https://doi.org/10.1016/j.engstruct.2016.09.019

31. Tsantilis AV, Triantafillou TC (2018) Innovative seismic isolation of masonry infills using cellular materials at the interface with the surrounding RC frames. Eng Struct. https://doi.org/10.1016/j.engstruct.2017.11.025

32. Mohammadi M, Akrami V, Mohammadi-Ghazi R (2011) Methods to improve infilled frame ductility. J Struct Eng. https://doi.org/10.1061/(ASCE)ST.1943-541X.0000322

33. Lin K, Totoev YZ, Liu H (2011) In-plane cyclic test on framed dry-stack masonry panel. In: Advanced materials research

34. Preti M, Bettini N, Plizzari G (2012) Infill walls with sliding joints to limit infill-frame seismic interaction: large-scale experimental test. J Earthq Eng 16:125-141. https://doi.org/ 10.1080/13632469.2011.579815

35. Preti M, Bettini N, Migliorati L, et al (2016) Analysis of the in-plane response of earthen masonry infill panels partitioned by sliding joints. Earthq Eng Struct Dyn 45:1209-1232. https://doi.org/10.1002/eqe.2703

36. Yuksel E, Ozkaynak H, Buyukozturk O et al (2010) Performance of alternative CFRP retrofitting schemes used in infilled RC frames. Constr Build Mater. https://doi.org/10. 1016/j.conbuildmat.2009.09.005

37. Koutas L, Pitytzogia A, Triantafillou TC, Bousias SN (2014) Strengthening of infilled reinforced concrete frames with TRM: study on the development and testing of textilebased anchors. J Compos Constr. https://doi.org/10.1061/ (ASCE)CC.1943-5614.0000390

38. European Committee for Standardization (2005) EN 14651: Test method for metallic fibres concrete. Measuring the flexural tensile strength

39. EN 12390-13 (2013) Testing hardened concrete-Part 13: Determination of secant modulus of elasticity in compression. Eur Comm Stand

40. EN 12664 (2001) Thermal performance of building materials and products-Determination of thermal resistance by means of guarded hot plate and heat flow meter methodsDry and moist products of medium and low thermal resistance. Eur Comm Stand

41. EN 1015-19 (1998) Methods of test for mortar for masonry-Part 19: Determination of water vapour permeability of hardened rendering and plastering mortars. Eur Comm Stand

42. De Risi MT, Del Gaudio C, Ricci P, Verderame GM (2018) In-plane behaviour and damage assessment of masonry infills with hollow clay bricks in RC frames. Eng Struct. https://doi.org/10.1016/j.engstruct.2018.04.065

43. Costa AA, Penna A, Magenes G (2011) Seismic performance of Autoclaved Aerated Concrete (AAC) masonry: from experimental testing of the in-plane capacity of walls to building response simulation. J Earthq Eng. https://doi. org/10.1080/13632461003642413

44. Celik OC (2016) Effect of AAC infill walls on structural system dynamics of a concrete building. J Earthq Eng. https://doi.org/10.1080/13632469.2015.1104757

45. Preti M, Migliorati L, Giuriani E (2015) Experimental testing of engineered masonry infill walls for post-earthquake structural damage control. Bull Earthq Eng 13:2029-2049. https://doi.org/10.1007/s10518-014-9701-2

46. Preti M, Neffati M, Bolis V (2018) Earthen masonry infill walls: Use of wooden boards as sliding joints for seismic resistance. Constr Build Mater 184:100-110. https://doi. org/10.1016/j.conbuildmat.2018.06.184

47. Preti M, Bolis V (2017) Masonry infill construction and retrofit technique for the infill-frame interaction mitigation: test results. Eng Struct 132:597-608. https://doi.org/10. 1016/j.engstruct.2016.11.053

Publisher's Note Springer Nature remains neutral with regard to jurisdictional claims in published maps and institutional affiliations. 